\title{
Woman on Buru Island
}

\author{
Aruadsu
}

\begin{abstract}
The existence of women in the customary structure often has a position as a complement of males so that their existence is limited by the stigma and norms that apply to the society. The existence of women in customs in Buru Island became an idea of how women are placed on the social economic space based on the inteprestation of men as customary rulers. This research is a qualitative study aimed at describing the existence of women in the customs of Buru Island. The research location focuses on three indigenous villages namely Kayeli village, Kubalahin and Wasi with consideration of the existence and the existence of adat that is still preserved. The number of informant that will be interviewed as many as 30 people taken in purposive. The analytical techniques used to follow the concepts given by Miles and Huberman include data reduction, data presentation and withdrawal of conclusions. The results showed that the distinction between men and women occurred through the process of socialization, strengthening and the construction of socio-cultural, even through the power of tradition. Women with all abilities and limitations only placed on complementary positions on customary structures ruled by men even though women are given certain status and awards but remain in male domination.
\end{abstract}

Keywords: Female, Feminism, Custom, Village, Buru

\section{INTRODUCTION}

Buru Island has an area of about 7,595.13 $\mathrm{km}^{2}$, the inhabitants of Buru regency based on data on population service and civil record in 2017 as many as 132,100 inhabitants consisting of 67,815 inhabitants of male population and 64,285 female population (central agency Stats, 2018)[1]. Of these, only about $10 \%$ are the indigenous population (Bupolo). Bupolo is the first name of Buru Island, also called Bupolo Waekolo. Waekolo was the name of the group of kinship (Noro or SOA) who expressed himself as a guardian or Geba eptugu (Geba $=$ people, Eptugu $=$ a guardian) at the center of the island. Based on customary recognition, the center of the island Buru with Mount Date and Lake Rana, belongs to all Bupolo people[2].

Women are a very remarkable person to discuss and discuss. Women are often associated with the existence of genres that become an attraction of their own to tell from many things, including women as humans with their rights[3].

Many studies in Indonesia saw the role of women into two categories. The first category is the role women see in terms of biologic as wives, mothers, and children or based on environmental traditions. Secondly, that women are based as individual beings and social beings not as companion husbands[4].

The struggle of women to realize equality with men by developing ability optimally in accordance with the principle of feminist struggle. The weakness and ignorance of women is not by nature but rather because it is not familiarity and is not given the same opportunity as men[5][6], but the obvious difference between the gender concept has spawned the good injustices Men, especially women. Consciously or not, when this feminist notion is seen at a glance, it seems that women are victims of the genre's concepts. The feminist contrast of male attitudes is seen from their behaviour that does not respect women, even tends to be arbitrarily.

Zainal in his research on female portrait bias Muna finds gender bias in female portraits reinforced by traditions governing and controlling the ideal female image [7][8]. There are three series of female life cycle rituals in Muna community in southeast Sulawesi called Kangkilo, Katoba, and Karia (3K). The puberty of males in the Muna community is more biological, while female puberty is both biological and social. With feminist anthropological perspectives it is asserted that the three female ritual sequences in the Muna community demonstrate a cultural effort in shaping the ideal female character on its reproduction side, which precisely confirms the treatment bias by Absence of ritual production for men in life cycle rituals[9]. These findings underscore that the female portraits in tradition are often paradoxical and not fair, where puberty of women is social and culture-formulated, while male puberty is biological.

Indraswari in his studies on women and poverty presents quantitative data at the macro level and qualitative data at the micro-level supports the statement that among the poor women is the poorest and reflects the The strong patriarchy culture that enviceing female inequality of gender worsened women's poverty and otherwise the poverty itself contributed to the increasingly serious gender inequality[10][11].

This research is to see a constructive pattern of public thought against indigenous women in Buru Island, so it is expected that there is a specific description of the existence of indigenous women in the lives of people in Buru Island.

\section{LITERATURE REVIEW}

\subsection{Custom and Woman}

Women are essentially oppressed and exploited, as well as attempts to end such suppression and exploitation [6]. The feminism movement was born from an idea that attempted to dismantling the ideology of suppression on behalf of gender, the search for the root of women's oppression, until the efforts to make a true liberation of women[12]. Feminism is the theoretical basis of the liberation movement of women. Various gender concepts are interpreted as a non-biological and non-nature difference[13]. The biological difference is that gender differences are the nature of God and are therefore permanently different. While gender is the difference in behavior between men and women who are socially constructed, the difference is not the nature or not the provisions of the Lord, but the results of the processed humans (male and female) through social and cultural processes The long[14]. The understanding of the cultural concept of gender is also a distinction in the role, behavior, mentality and emotional character between men and women who thrive in society. Thus gender is the cultural expectations for women and men and the social of men and women[15]. The concept of marginalization, Fakih and Murniati, represents feminist thought in Indonesia, emphasizes 
marginalization as one of the manifestations of gender injustice[16]. They interpreted marginalization as a process that resulted in poverty or depletion on a particular gender, in which case the woman is caused by her own Gendernya[17]. There are several differences in the type and shape, place and time as well as mechanisms of marginalization of women due to gender differences. In terms of its source can be derived from government policy, beliefs, religious interpretation, tradition and customs beliefs or even the assumption of science.

\subsection{Feminism}

Feminism is the understanding or belief that women are truly part of the human realm, not from others that demand equality with men in every aspect of life, without looking at the nature and its fitrah. This equality is usually referred to as the term gender equality[18][19]. In terms of gender equality can be interpreted by the similarity of male and female conditions in obtaining their rights as social or human beings[20].

It is expected to be able to act and participate in all activities such as politics, economics, social, culture, education and similarities in enjoying development. Feminism according to Manggi Humin is an ideology of female loading because the inherent in all of his approaches is the belief that women are not as fair as the gender[21]. According to Mansour Fakih, feminism is the movement and consciousness that departs from the assumption that women are essentially suppressed and exploited, as well as attempts to end the suppression and exploitation. The feminism movement was born from an idea that attempted to disassemble the ideology of suppression on behalf of gender, the search for the roots of women, to the creation of a true liberation of women[22]. Feminism is the theoretical basis of the liberation movement of women.

The emergence of the feminism movement that championed equal rights between men and women in some countries is actually a form of protest against the social structure that puts women always in an inferior position above the superiority of Men[23]. The work Agenda of the main feminist movement is to foster a strong impression that individually, women and men are the same. The arguments they build are based on the philosophy of existentialism initiated by Satre which states that human existence is not innate, but rather an option [4]. Therefore the right of each individual to choose his identity. Therefore, the education concept is developed, which is the concept of education that introduces a gender-free concept to boys and girls. This concept assumes that men and women have the same potential to be masculine or feminine, therefore they must be treated equally[24].

However, among the feminismini movements there are still considering gender roles between men and women, however, different, and therefore the division of their duties becomes different. Yet other feminism movements show symptoms that are really vulgar and radical. In the liberal feminism view, women have essentially similarities to men in terms of their rights and potential rationality[25]. But since women are always placed in an inferior position especially in the domestic region, then the more dominant it develops is its emotional aspect. Therefore, they look to be given a strong legal umbrella so that the equality of rights between women and men is more able to be assured. In Indonesia, modern feminists criticize Indonesia's Indonesian Marriage Act No. 1 year 1974 which is lame because it gives more flexibility to the husband by far greater concern than to women as wives. While in radical feminism, the family is seen as an oppressive institution. The Marxist feminists, for example, condemned the family as an economic unit, not as an emotional unit[26]. Women become unpaid laborers and the bourgeois ideological source in the family[27][28]. Even though women can do the job outdoors, their obligation to keep working inside the house remains attached in order to provide benefits to male activities. Therefore, to make women more productive, they have women to enter the public sector. By having material, women's bargaining position will be equally strong with men[29].

\section{Method}

The research was conducted in Wasi village, Kayeli Village and Kubalahin village, Buru Regency. The three villages were chosen as the research locations because of the population percentage as well as the higher aspects of social culture life compared to other villages in Buru Regency[30]. The number of informant that will be interviewed as many as 30 people taken purposive in consideration of respondents are considered as related parties to achieve research objectives (Koyan, 2014). The informant in the study consisted of indigenous peoples, public figures, merchants, farmers and communities residing at the research site.

In the interview step researchers conducted a thorough interview with the related parties[31] and provided the questionnaire to the informant at the site in response to the implementation of traditions relating to women [18]. Researchers are also looking for complementary information [19] regarding customs over the Internet as well as the study of libraries using government documents/archives[32] related to local traditions.

The analytical techniques used in this study are the analysis of qualitative data following the concepts given by Miles and Huberman and Spradley[33]. Miles and Huberman, suggests that activities in the analysis of qualitative data are conducted interactively and ongoing continuously at every stage of the research until it is complete and the data until saturated[34]. Activity in data analysis is data reduction, data presentation, withdrawal of verification conclusion[35].

\section{Result}

\subsection{Structure of Women in Customs in the Island Buru}

In general, the existence of women (Anavina) is a part that blends with various customs and the existence of social life of the people who inhabited Pulau Buru. As an integral part, women are viewed as equal and equal to men, in relation to the various roles and positions performed and owned by men are considered to be lived by women.

The woman in the Buru customary general occupies an important position as found in three research locations namely Kubalahin Village, Kayeli Village, and Wasi village[36]. At these three locations put women in its function as a creature given the ability to contain children, breastfeeding and care so that people Bupolo (a designation for the original tribe of the island Buru) put women in a position according to their nature. This condition is understood because in the myth of 
Bupolo against the mountain and water which is a representation of the symbols of men and women. These two representations should always be visible or appear in each of their activities ranging from processing natural resources to obtaining the results. The people of Kubalahin village see women in their functions to take care of the household and raise children, Wasi Village People understand the function of women to obtain mating treasures. Where women are placed as in the implementation of activities or activities but in the structural position of women's position becomes merely complementary to the assumption that women as a complement to male needs are increasingly apparent[37].

In the results of the field findings, women's abundance in three domestic activity research locations has long been attached to women[38]. On the morning of women's activities in the social environment it is a determination that the women of Buru play an important role in the customs and customs that exist.

\subsection{Indigenous Women's Traditions in the Island Buru}

As in other societies, in indigenous communities in the island of Burupun, men play important roles in both social and religious areas. Leader of family, community or group, village, and tribe and the leadership of life cycle rituals such as Salametan (Hajat), initiation, marriage, death, and marriage ceremony and death), Hajat Wawar (traditional religious rituals related to natural events), But it does not mean that the indigenous men of Buru control the joints of people's lives. The indigenous women of Buru Island in addition to having the same functions and roles as men also have functions and roles that are distinctive and not allowed by men. In other words, the men and women of the customary Buru both have Important functions and roles. The customary men of Buru are not dominating and likewise the customary women of Buru are not considered to be subordinated.

As in the traditional procession that is held is the wedding event in Buru[39]. This customary process can be said that the full contributing is a man of than with women however, indeed on his brother the number of women who are incorporated in customs not as much as men. With a sufficiently dominant number having a prominent function in some ritual processions although hierarchical is not a core ritual led directly by the Chairman of the Adat and other elders. Women have more roles than ritual preparation events to post rituals. Since the preparation of the day before both at home and beyond, during the ritual implementation to the completion of the ritual ceremony, women are more adorning the ritual on the surface. Women since early in the morning are busy with activities at home preparing groceries, cooking, and washing vegetables until the work that is commonly done in the procession of customs implementation

\section{Discussion}

Cultural understanding of women's problems, status and role in social life vary greatly according to the development of the situation and time and depending on how those understandings relate to the position of the people Women in different communities. Anthropologists, who were investigating women's positions in the development of the Community unconsciously participated in the debate over the origins and universality of the female periphery[40][41]. Thus the study of the hierarchical relationship between men and women became important[42].

Men and women of natural, bilogist and genetic difference, are a reality, as the nature of God that cannot be changed. But the then-bearing debate is when this natural distinction then raises a diverse understanding of each and every person and community[43]. These differences of understanding are further known by the concept of gender, namely some traits that are attached to men and women who are socially and culturally constructed[44]. For example stereotype female that is known to be gentle, motherly, emotional or more patient. While men are considered strong, rational, mighty and so on. Stereotype like this is interchangeable and can be different in each community, depending on the culture and the value system built[45].

In principle, there is a biological difference between men and women, it is really not a problem and therefore it is not necessary to be disputed. Naturally women with the organ of the reproductions can conceive, give birth and lactation, and then have the role of gender as nurses, caregivers, and educators is the thing that natural problem is apparently the female gender role is assessed and Much lower than the male gender role[46]. The role of gender turns out to be injustice, discriminating and suppression of women. It is essentially a social construction culture built by a specific community.

The oppressed of women, anthropologically, was seen by Sherry Ortner due to a value system given a culturally specific meaning[47][48]. Ortner puts women's remains on the ideology and cultural symbols. In the universal culture, the act of women, according to Ortner, is the manivestation of the understanding between culture and nature which is then compared to the position of men and women in social roles. In general, culture gives distinction between human society and nature. Culture seeks to control and master the nature that is further utilized for various interests[49]. Therefore, culture is in superior position and the nature is inferior. Culture is created to master, manage and control nature to sustain the survival of the community[50]. In conjunction with men and women, women are always associated with nature, and men are associated with culture. It is therefore natural that women are in controlled, controlled and mastered positions. This concept is in common with the Turkish concept of women, that women are associated with land and men associated with seed (rice) as an understanding of reproduction[51].

This is what happened in Buru Island until it became customary that the state and position of women were not separated from male shadows. In the procession of customary implementation in Buru Island illustrates that female roles and functions are significantly[52].

\section{CONCLUSION}

In general, the history of distinction between men and women occurs through the process of socialization, strengthening and construction of socio-cultural, religious, even through state power. Through lengthy processes, gender is gradually becoming as if God's nature or biological provisions are irreversible. As a result, gender affects human beliefs and community culture about how men and women think and act in accordance with these social provisions. This view of the gender's perspective is a theoretical debate, when judging 
from the economic perspective, the sub-ordination of the position of women under the males is said to be rooted in dependence. Economic. According to a political perspective, because women have no control over production properties and tools, women do not have access to participate in the political sphere. Different from the cultural perspective that the culture is strongly influenced by religious ethics, resulting in the position and role of women are also formed by referring to the values contained in religious teachings in a country. But in the role of women in the customary on the island of Buru is a reflection of the existence of women who are not inferior to the role of men in the implementation of the traditional procession is being island Buru. This illustrates that the role of women in traditional rituals in the island of Buru is very black and can be regarded as a benchmark of the function and position of women in the implementation of custom.

\section{REFERENCES}

[1] H. Hamiru et al., "Eucalyptus Oil Workers," Int. J. Sci. Technol. Res., vol. 8, no. 9, 2019.

[2] M. C. B. Umanailo, I. Hamid, M. Nawawi, S. Pulhehe, S. Yusuf, and A. T. Bon, "Utilization of Qualitative Methods in Research Universities," in Proceedings of the International Conference on Industrial Engineering and Operations Management, 2019, pp. 2076-2081.

[3] M. C. B. Umanailo, R. Umanailo, R. Bugis, and A. T. Bon, "Empowerment Community in Buru Regency," in Proceedings of the International Conference on Industrial Engineering and Operations Management, 2019, pp. 2070-2075.

[4] M. C. B. Umanailo, "Strategi Bertahan Hidup Petani Padi Gogo di Pulau Buru," J. Ekon. Pertan. dan Agribisnis, vol. 3, no. 1, pp. 50-58, Jan. 2019.

[5] M. C. B. Umanailo, "Consumption Diversification of Local Community," J. AGRISEP Kaji. Masal. Sos. Ekon. Pertan. dan Agribisnis, vol. 18, no. 1, pp. 61-74, Mar. 2019.

[6] A. L. Wabula, M. Musyawir, A. Irmawati, B. Rebel, D. M. Darajat, and M. C. B. Umanailo, "Maghrib Movement," Int. J. Sci. Technol. Res., vol. 8, no. 9, 2019.

[7] L. Rumkel, B. Sam, and M. C. B. Umanailo, "Village Head Partnership, Village Consultative Body and Customary Institution in Village Development," Int. J. Sci. Technol. Res., vol. 8, no. 8, pp. 1058-1063, 2019

[8] R. I. Umasugi, C. C. Costa, M. Apriyanto, M. C. B. Umanailo, and N. Mufidah, "Dominance of Economic Capital in the Political," Int. J. Sci. Technol. Res., vol. 8, no. 9, 2019.

[9] M. C. B. Umanailo, "Discourse on the Consumerist Community Consumption," J. Soc. Sci. Res., vol. 5, no. 54, pp. 1181-1186, Apr. 2019.

[10] R. Bugis et al., "Workers in the Namlea Market," Int. J. Sci. Technol. Res., vol. 8, no. 9, 2019.

[11] M. C. B. Umanailo, M. Nawawi, and S. Pulhehe, "KONSUMSI MENUJU KONSTRUKSI MASYARAKAT KONSUMTIF," Simulacra, vol. 1, no. 2, pp. 203-211, 2018.

[12] A. Hasan Afandi and M. C. B. Umanailo, "Watudakon Citizens 'Social Conflict on Joker Toll Road Development in 2017 in Kesamben District, Jombang Regency," J. Soc. Sci. Res., vol. Special Is, no. 5, pp. 656-661, 2018.

[13] M. C. B. Umanailo, N. Handayani, A. Masniati, S. H. Makatita, and S. Lisaholit, "The Urbanization and Diversification of Farmland Namlea Village," Int. J. Sci. Technol. Res., vol. 8, no. 8, pp. 1049-1053, 2019.

[14] M. C. B. Umanailo, "Overview of Phenomenological Research," 2019, pp. 1-6.

[15] M. C. B. Umanailo, "Studi pada Masyarakat Desa Waimangit Kabupaten Buru," SOCA, vol. 12, no. 12, pp. 63-74, 2018.

[16] S. Rachman, H. Hamiru, M. C. B. Umanailo, Y. Yulismayanti, and
H. Harziko, "Semiotic Analysis of Indigenous Fashion in The Island of Buru," Int. J. Sci. Technol. Res., vol. 8, no. 8, pp. 15151519, 2019.

[17] M. C. B. Umanailo, "BUPOLO " Movement. 2019.

[18] S. Yusuf, M. C. B. Umanailo, R. N. Putri, D. Qhuril, M. Ely, and D. Darma, "Village Institution Relations in the Utilization of Village Funds in Namlea District," Int. J. Sci. Technol. Res., vol. 8, no. 8, 2019.

[19] S. S. F. Assagaf et al., "Construction of the Village as a Development Shaft in the Island Buru," Int. J. Sci. Technol. Res., vol. 8, no. 9, 2019.

[20] M. C. B. Umanailo et al., "Cybercrime Case as Impact Development of Communication Technology That Troubling Society," Int. J. Sci. Technol. Res., vol. 8, no. 9, 2019.

[21] M. Nawawi et al., "The Village Kalesang Program as a Poverty Alleviation Community," Int. J. Sci. Technol. Res., vol. 8, no. 10, 2019.

[22] M. C. B. Umanailo et al., "Comprehension To Village," 2018, pp. $1-2$.

[23] M. C. B. Umanailo, MASYARAKAT BURU DALAM PERSPEKTIF KONTEMPORER, vol. 53, no. 9. 2015.

[24] M. C. B. Umanailo, Sosiologi Hukum, 1st ed. Namlea: FAM PUBLISHING, 2016.

[25] M. C. B. Umanailo and T. Yatno, Kajian dan Analisis Sosiologi Dalam Bentuk Kumpulan Essay, Makalah dan Opini. 2015.

[26] M. C. B. Umanailo, MARGINALISASI BURUH TANI AKIBAT ALIH FUNGSI LAHAN, 1st ed. Namlea: FAM PUBLISHING, 2016.

[27] M. C. B. Umanailo, M. Yulisvestra, K. K. Oki, W. Mulyasari, and R. Ridwan, "The Thought of Emile Durkheim in the Contestation of Development in Indonesia," Int. J. Sci. Technol. Res., vol. 8, no. 8, 2019.

[28] A. Wael et al., “" Bupolo 'Motion Reading," Int. J. Sci. Technol. Res., vol. 8, no. 9, 2019.

[29] L. T. Muharlisiani et al., "The role of Customer Service through Customer Relationship Management ( CRM ) to Increase Customer Loyalty and Good Image," Int. J. Sci. Technol. Res., vol. 8, no. 10, 2019.

[30] A. Ervina, D. Zulmi, R. Ariesta, Y. Aridawarni, A. Aminah, and M. C. B. Umanailo, "The Relationship of Patterns Use of Time and Income Family with Juvenile Delinquency in Junior High School Students at Lebak Distric," Int. J. Sci. Technol. Res., vol. 8, no. 10, 2019.

[31] A. Rahmat, A. D. Gs, N. Djafri, I. Shofwan, and M. C. B. Umanailo, "The Influence of Family Leadership towards Adolescent Social Values in the City of Gorontalo," Int. J. Sci. Technol. Res., vol. 8, no. 10, 2019.

[32] A. D. E et al., "The Existence of Waranggana in Tayub Ritual," Int. J. Sci. Technol. Res., vol. 8, no. 10, 2019.

[33] W. Rumaolat, E. Dusra, I. S. Tunny, M. S. J. Malisngorar, S. Cahyawati, and M. C. B. Umanailo, "Relationship Diet and Regulate Blood Sugar in the Elderly with DM Type li in Waimital Village , Kairatu District , West Seram Regency," Int. J. Sci. Technol. Res., vol. 8, no. 10, 2019.

[34] N. S. Wisnujati et al., "Public Relations Management through Management by Objective," Int. J. Sci. Technol. Res., vol. 8, no. 10, 2019.

[35] I. Shofwan et al., "Non-Formal Learning Strategy Based on Tahfidz and Character in the Primary School," Int. J. Sci. Technol. Res., vol. 8, no. 10, 2019.

[36] M. Jannah, R. Widohardhono, F. Fatimah, D. K. Dewi, and M. C. B. Umanailo, "Managing Cognitive Anxiety through Expressive Writing in Student-Athletes," Int. J. Sci. Technol. Res., vol. 8, no. 10, 2019.

[37] W. Malmia et al., "Problem-Based Learning as an Effort to Improve Student Learning Outcomes," Int. J. Sci. Technol. Res., vol. 8, no. 9, 2019.

[38] B. Sam et al., "Female Feminism in the Customary Island of Buru," Int. J. Sci. Technol. Res., vol. 8, no. 8, 2019. 
[39] M. C. B. Umanailo, ILMU SOSIAL BUDAYA DASAR, 1st ed. Namlea: FAM PUBLISHING, 2015.

[40] S. Prafitriyani, I. Magfirah, N. F. Amir, A. Irmawati, and M. C. B. Umanailo, "Influence of Emotional Intelligence on Mathematics Learning Outcomes of Class VII Middle School 9 Buru Students," Int. J. Sci. Technol. Res., vol. 8, no. 10, 2019.

[41] L. J. Buton et al., "The Effect of Nasa Liquid Organic Fertilizer Concentration and Planting Distance to Growth and Production of Beans," Int. J. Sci. Technol. Res., vol. 8, no. 9, 2019.

[42] M. Muhasidah et al., "Healthy Food with Children Learning Achievements at Makassar City Elementary School," Int. J. Sci. Technol. Res., vol. 8, no. 10, 2019.

[43] M. S. J. Malisngorar et al., "Effect of Health Education Knowledge about Antenatal Care Mothers against Hamlet Land Shake the District Huamual West Seram Regency," Int. J. Sci. Technol. Res., vol. 8, no. 10, 2019.

[44] M. Y. Zakaria, W. Malmia, A. Irmawati, N. F. Amir, and M. C. B. Umanailo, "Effect Mathematics Learning Achievement Motivation on Junior High School Students 1 Namlea," Int. J. Sci. Technol. Res., vol. 8, no. 10, 2019.

[45] R. Umanailo, M. Nawawi, M. C. B. Umanailo, S. Malik, and I. Hentihu, "Conversion of Farmland Namlea Subdistrict," Int. J. Sci. Technol. Res., vol. 8, no. 8, 2019.

[46] R. Djibu, I. Shofwan, and M. C. Basrun, "Development of Andragogical Learning Model to Improve Life Skill for Teenagers Who Drop Out of School in Gorontalo City," Int. J. Sci. Technol. Res., vol. 8, no. 10, 2019.

[47] M. Apriyanto and M. C. B. Umanailo, "Decrease Polyphenols , Ethanol, Lactic Acid, and Acetic Acid during Fermentation with Addition of Cocoa Beans Innoculum," Int. J. Sci. Technol. Res., vol. 8, no. 9, 2019.

[48] B. S. Amanto, M. C. B. Umanailo, R. S. Wulandari, T. Taufik, and S. Susiati, "Local Consumption Diversification," Int. J. Sci. Technol. Res., vol. 8, no. 8, 2019.

[49] M. C. B. Umanailo, "Overview Phenomenological Research," pp. $1-6$.

[50] M. C. B. Umanailo, "Integration of Community Empowerment Models [Pengintegrasian Model Pemberdayaan Masyarakat]," Proceeding Community Dev., vol. 2, p. 268, Mar. 2019.

[51] A. Assagaf et al., "Educational Political Policy," Int. J. Sci. Technol. Res., vol. 8, no. 9, 2019.

[52] M. C. B. Umanailo, "Kalesang Dorp in Context De Bouw van Village." 